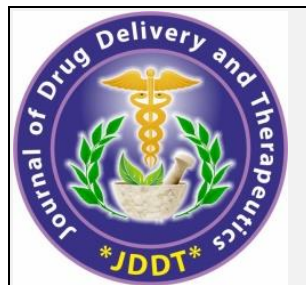

Open Access
Available online on 15.12.2020 at http://jddtonline.info

\section{Journal of Drug Delivery and Therapeutics}

Open Access to Pharmaceutical and Medical Research

(C) 2011-20, publisher and licensee JDDT, This is an Open Access article which permits unrestricted non-commercial use (CC By-NC), provided the original work is properly cited

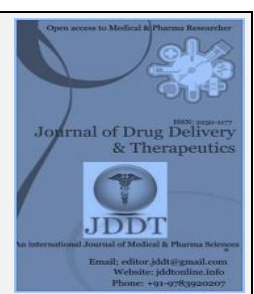

Research Paper

\title{
Nephroprotective Effect of Asgand Powder (Withania somnifera Dunal) on Cisplatin Induced Renal Injury in Rats
}

\author{
Farhan Akhtar ${ }^{*}$, Misbahuddin Azhar², Mohd Aslam³ ${ }^{3}$ Kalim Javed ${ }^{4}$ \\ ${ }^{1}$ Medical Officer (Unani), Government Unani Hospital, Asara, Baghpat, India \\ 2 Research Officer Scientist-III, Regional Research Institute of Unani Medicine, Aligarh, India \\ ${ }^{3}$ Professor, School of Unani Medical Education and Research, Jamia Hamdard, New Delhi, India \\ ${ }^{4}$ Professor, Dept. of Chemistry, School of Chemical \& Life Sciences, Jamia Hamdard, New Delhi, India
}

\begin{abstract}
Background: The nephroprotective effect of crude powder of Asgand (Withania samnifera Dunal) was studied against cisplatin induced renal toxicity in wistar albino rats of either sex.

Results: The powder of Withania somnifera Dunal at dose level 700 and $1400 \mathrm{mg} / \mathrm{kg}$ body wt/day showed reduction in elevated blood urea, serum creatinine and uric acid. It was found to protect kidney damage by cisplatin induced nephrotoxicity as evidenced by oral administration of Asgand (Withania samnifera Dunal) (700 mg/kg) inhibited the rise in blood urea nitrogen (121.7\%), Serum cratinine (76.64\%), and uric acid $(92.7 \%)$. There were $92.71 \%$ inhibition in the rise of BUN, $92 \%$ inhibition in the rise of serum creatinine and $106.6 \%$ inhibition in the rise of uric acid with $1400 \mathrm{mg}$.
\end{abstract}

Conclusion: The findings suggest that the famous Unani herb Asgand Powder possesses marked nephroprotective activity and could offer a promising role in the treatment of acute renal injury caused by nephrotoxins like cisplatin.

Keywords: Withania somnifera Dunal, Cisplatin, Asgand, Nephroprotection, Unani Medicine

Article Info: Received 11 Oct 2020; $\quad$ Review Completed 17 Nov 2020; $\quad$ Accepted 28 Nov 2020; $\quad$ Available online 15 Dec 2020

Cite this article as:

Akhtar F, Azhar MU, Aslam M, Javed K, Nephroprotective Effect of Asgand Powder (Withania somnifera Dunal) on Cisplatin Induced Renal Injury in Rats, Journal of Drug Delivery and Therapeutics. 2020; 10(6-s):22-25

http://dx.doi.org/10.22270/jddt.v10i6-s.4580

*Address for Correspondence:

Dr. Farhan Akhtar, Medical Officer (Unani), Governemnt Unani Hospital, Asara, Baghpat, Uttar Pradesh-India

\section{INTRODUCTION}

Acute renal failure refers to the sudden and usually reversible loss of renal function, which develops over a period of days or weeks. Among the causes of acute renal failure acute tubular necrosis, which occurs due to ischemia or nephrotoxins like cisplatin and gentamicin (aminoglycoside) is most common, accounting for $85 \%$ of the incidences. Cisplatin is an important anticancer or antineoplastic drug and especially effective for the treatment of solid tumors of testes, ovaries, breast, lungs, bladder etc. ${ }^{1-3}$ Its use is limited due to nephrotoxicity, which is a major clinical problem, seen in about $20 \%$ of patients despite the use of saline hydration and diuretics, and it is characterized by decreased glomerular filtration and tubular injury. ${ }^{4-6}$

Although the mechanism of cisplatin induced renal injury is not well understood. It may involve direct interference with tubular or mitochondrial transport processes ${ }^{7}$ covalent modification of cellular constituents ${ }^{8}$ or it has been suggested that oxygen free radicals play an important role.911 But some hypotheses are given for explaining their mechanism. Experimental and clinical studies showed that after cisplatin injection, a marked decrease in renal blood flow and glomerular filtration rate was also observed.12-13 Cisplatin increases lipid peroxidation in renal cortical slices. ${ }^{9,14-15}$ It has been reported that the administration of free radical scavengers and antioxidants such as super oxide dismutase, sodium selenite ${ }^{16}$ offered partial protection of the kidney against cisplatin toxicity. Although the mechanism of cisplatin renal toxicity is not clear, it has been suggested that oxygen free radicals play an important role. ${ }^{\text {The }}$ crude extract of Ginkgo biloba (Family: Ginkgoaceae) protects kidney slices against cisplatin induced lipid peroxidation and decreased uptake of $p$-aminohippuric acid. ${ }^{9}$ 
Search for nephroprotective agents has made man turn to alternative sources viz indigenous system of medicines especially Unani and Ayurveda. That has a rich literature from ancient time and provides a cheap, effective and safe medicine through it source of herbal, mineral and animal origin drugs. ${ }^{17}$

Asgand (Withania somnifera, Dunal) belongs to the family Solanaceae. It is very familiar name in Unani as well as in other traditional systems of medicine for its multifarious properties, due to the similarity between the restorative properties of Asgand root and Ginseng root it is also called 'Indian ginseng'. In Tibbe Unani, Asgand is well known for its therapeutic properties as rejuvenator, strengthen, immunomodulator, diuretics, adoptogenic etc. 18-19 The fresh roots are preferred for medicinal uses, two type of asgand mentioned in Unani literature. Our preliminary studies showed that Asgand (Withania somnifera, Dunal) protect the kidney damage against the cadmium chloride induced renal damage. ${ }^{20}$ Rhubarb (Rheum emodi) against gentamicin, cadmium chloride, mercuric chloride and potassium dichromate, ${ }^{21}$ Kulthi (Dolichos biflorous) against gentamicin and mercuric chloride induced nephrotoxicity, ${ }^{22-23}$ Kundur (Boswellia serrata Roxb.) ${ }^{24}$ Khar-e-Khasak Khurd (Tribulus terrestris) ${ }^{25}$ Hilteet (Refula foetida Regal) ${ }^{26}$ against gentamicin induced toxicity in experimental animals.

\section{Objective of the study}

The objective of this study was taken to evaluate the efficacy of the crude power of Withania somnifera Dunal, against cisplatin-induced nephropathy.

\section{MATERIALS AND METHOD}

\section{Plant Material}

The Asgand (Withania somnifera Dunal) was procured from Asian Traders, Kharibaoli, Delhi. The authenticity of Asgand (Withania somnifera Dunal) was established by the matching with authentic specimen available in Dept. of Ilmul Advia
F/o Medicine (U), Jamia Hamdard, New Delhi-110062. The root of Asgand (Withania somnifera Dunal) was dried and converted into fine powder (Asgand power=AP) and finally suspended in vehicle before its administration per orally.

\section{Animals}

Healthy albino rats of Wistar strain of either sex weighing 130-250 gms (aged 60-90days) were used for this study. Rats were obtained from Central Animal House Facilities, Jamia Hamdard, New Delhi. They were kept under standard laboratory conditions (Temperature and humidity controlled) and fed with standard diet. Water was allowed ad libitum. The study was conducted after obtaining Institutional animal ethical committee Clearance.

\section{Research designed}

Three days after acclimatization, the rats were assigned randomly to four equal experimental groups having six animals each. The group-I served as control and was injected with distilled water and orally administered gum acacia solution $(2 \% \mathrm{w} / \mathrm{v})$ for 7 days. The group-II was given cisplatin $(1 \mathrm{mg} / \mathrm{kg} /$ day, intra peritoneal) for four days and orally administered same as group-I, ${ }^{27}$ group-III was treated with powder of Withania somnifera Dunal in the dose of 700 $\mathrm{mg} / \mathrm{kg}$ body $\mathrm{wt}$. orally suspended in acacia solution $(2 \%$ $\mathrm{w} / \mathrm{v}$ ), group-IV was administered the test drug in the dose of $1400 \mathrm{mg} / \mathrm{kg}$ body wt., orally. Group III and IV also received cisplatin $1 \mathrm{~g} / \mathrm{kg} /$ day intra peritoneal. On the next day the blood samples were collected, serum was separated by centrifuging at $3000 \mathrm{rpm}$ for $10 \mathrm{~min}$. Serum were analyses for blood urea, serum creatinine and uric acid levels. ${ }^{28}$

\section{Statistical Analysis:}

Data were expressed as Mean+S.E.M and analyzed by oneway analysis of variance (ANOVA) followed by Dunnett's ' $\mathrm{t}$ ' test. The probability level less than $5 \%$ considered to be significant.

\section{RESULTS}

Table-1: Effects of Asgand (Withania somnifera Dunal) on BUN in Cisplatin induced nephrotoxicity in rat model (Oral treatment period -7 days)

\begin{tabular}{|c|c|c|c|c|c|}
\hline Groups & Treatment & Dose & $\begin{array}{c}\text { BUN Level (mg/dl) } \\
\text { (Mean } \pm \text { SEM) }\end{array}$ & \% of change & \% of inhibition \\
\hline I & Control (Vehicle) & $10 \mathrm{ml} / \mathrm{KG}$ & $20.19 \pm 0.68$ & - & - \\
\hline II & Cisplatin (Toxicant) & $1 \mathrm{mg} / \mathrm{Kg} /$ day & $29.8 \pm 1.15^{\mathrm{a} *}$ & 100 & - \\
\hline III & AP + Toxicant & $700+1 \mathrm{mg} / \mathrm{Kg} /$ day & $18.10 \pm 0.91^{\mathrm{b} *}$ & -21.7 & 121.7 \\
\hline IV & AP + Toxicant & $1400+1 \mathrm{mg} / \mathrm{Kg} /$ day & $20.89 \pm 1.09^{\mathrm{b}}$ & 7.3 & 92.7 \\
\hline
\end{tabular}

$\mathrm{N}=6, \mathrm{BUN}=$ Blood urea nitrogen, ${ }^{*}$ Statistically significant, ain comparison with control, bin comparison with toxicant, ${ }^{*} \mathrm{P}<0.01$

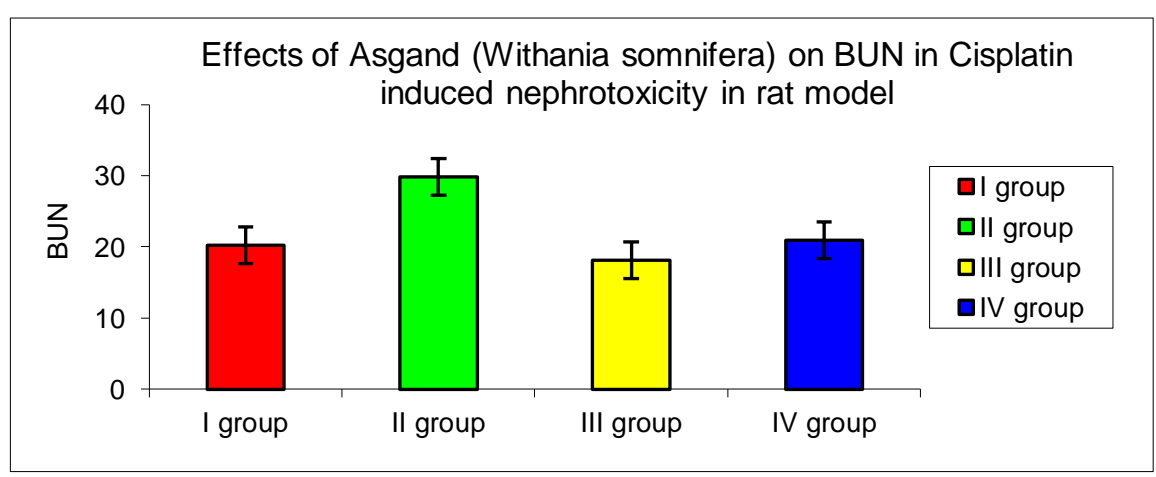

Figure-1: Effects of Asgand (Withania somnifera Dunal) on BUN in Cisplatin induced nephrotoxicity in rat model 
Table-2: Effects of Asgand (Withania somnifera Dunal) on serum creatinine in Cisplatin induced nephrotoxicity in rat model (Oral treatment period -7 days

\begin{tabular}{|c|c|c|c|c|c|}
\hline Groups & Treatment & Dose & $\begin{array}{c}\text { S.Cr Level (mg/dl) } \\
\text { (Mean } \pm \text { SEM) }\end{array}$ & \% of change & \% of inhibition \\
\hline I & Control (Vehicle) & $10 \mathrm{ml} / \mathrm{KG}$ & $1.44 \pm 0.11$ & - & - \\
\hline II & Cisplatin (Toxicant) & $1 \mathrm{mg} / \mathrm{Kg} /$ day & $2.81 \pm 0.21^{\mathrm{a}^{*}}$ & 100 & - \\
\hline III & AP + Toxicant & $700+1 \mathrm{mg} / \mathrm{Kg} /$ day & $1.76 \pm 0.13^{\mathrm{b} *}$ & 23.40 & 76.6 \\
\hline IV & AP + Toxicant & $1400+1 \mathrm{mg} / \mathrm{Kg} /$ day & $1.55 \pm 0.10^{\mathrm{b} *}$ & 8.0 & 92 \\
\hline
\end{tabular}

$\mathrm{N}=6$, S.Cr = Serum Creatinine, ${ }^{*}$ Statistically significant, ain comparison with control, bin comparison with toxicant, ${ }^{*} \mathrm{P}<0.01$

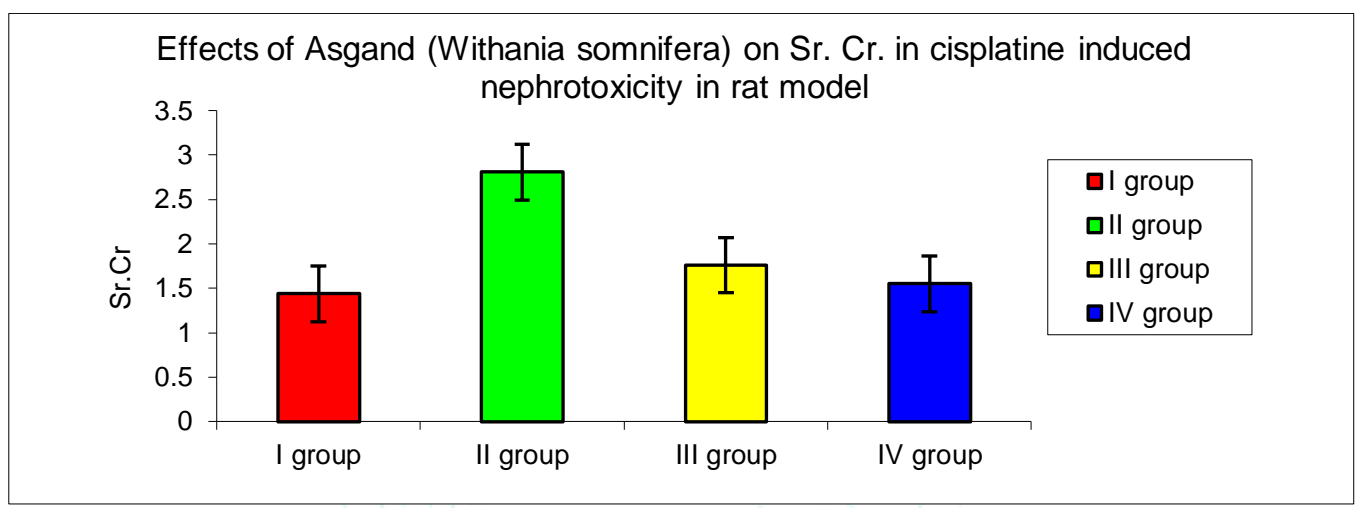

Figure-2: Effects of Asgand (Withania somnifera Dunal) on Sr. Cr. in cisplatine induced nephrotoxicity in rat model

Table-III: Effects of Asgand (Withania somnifera Dunal) on uric acid in Cisplatin induced nephrotoxicity in rat model (Oral treatment period -7 days)

\begin{tabular}{|c|c|c|c|c|c|}
\hline Groups & Treatment & Dose & $\begin{array}{c}\text { Uric Acid Level (mg/dl) } \\
\text { (Mean } \pm \text { SEM) }\end{array}$ & \% of change & \% of inhibition \\
\hline I & Control (Vehicle) & $10 \mathrm{ml} / \mathrm{KG}$ & $8.92 \pm 1.03$ & - & - \\
\hline II & Cisplatin (Toxicant) & $1 \mathrm{mg} / \mathrm{Kg} /$ day & $13.19 \pm 0.83^{*}$ & 100 & - \\
\hline III & AP + Toxicant & $700+1 \mathrm{mg} / \mathrm{Kg} /$ day & $9.23 \pm 0.62^{\mathrm{b}^{*}}$ & 7.3 & 92.7 \\
\hline IV & AP + Toxicant & $1400+1 \mathrm{mg} / \mathrm{Kg} /$ day & $8.64 \pm 0.61^{\mathrm{b}}$ & -6.6 & 106.6 \\
\hline
\end{tabular}

$\mathrm{N}=6, \mathrm{UA}=$ Uric Acid , *Statistically significant, ain comparison with control, bin comparison with toxicant, ${ }^{*} \mathrm{P}<0.01$

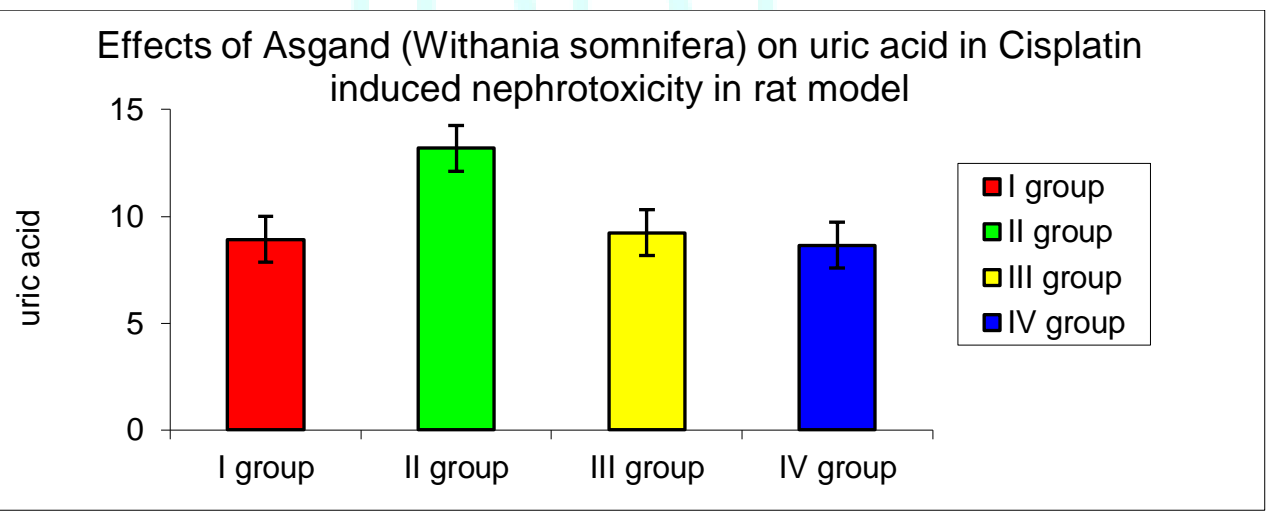

Figure-3: Effects of Asgand (Withania somnifera Dunal) on Uric acid. in cisplatine induced nephrotoxicity in rat model

Group I (Control) was compared Group II (Toxicant) for observation of change in the parameters. The Group III and Group IV were compared with Group II to observe the Inhibition. The inhibition was calculated in term of percentage of change in comparison to control. The level of the markers increased significantly in cisplatin treated (group-II) animals in comparison to Control (group-I). Cisplatin treatment caused nephrotoxicity as evidenced by marked elevation in blood urea nitrogen (BUN) 47.59\%, serum creatinine (SC) $95.13 \%$ and uric acid (UA) $47.86 \%$ as shown in table I,II \& III and table-1,2 \& 3.

The elevation of serum markers were significantly reduced by the oral administration of Asgand powder (Withania somnifera Dunal) in the dose $700 \mathrm{mg} / \mathrm{kg}$, inhibited the rise in BUN $121.7 \%$, SC $76.64 \%$ and UA $92.7 \%$. There were $92.71 \%$ inhibition in the rise of BUN, $92 \%$ inhibition in the rise of SC 
and $106.6 \%$ inhibition in the rise of UA with the dose 1400 $\mathrm{mg} / \mathrm{kg}$.

\section{DISCUSSION}

The study demonstrates renal injury due to cisplatin which was evidenced by the elevated blood urea and serum creatinine level. Crude powder of Asgand was found to reduce the elevated blood urea nitrogen, serum creatinine and uric acid. It has been evident from the data that the results are not significantly varying with respect to dose of $700 \mathrm{mg} / \mathrm{kg}$ and $1400 \mathrm{mg} / \mathrm{kg}$. Therefore the dose $700 \mathrm{mg} / \mathrm{kg}$ can be consider pharmacologically effective dose. Induction of nephrotoxicity by cisplatin is assumed to be a rapid process involving reaction with proteins in renal tubules. Evidence points out that cisplatin induce nephrotoxicity partly via oxidative stress. One mechanism proposed is that cisplatin induces renal damage by free radical generation, by altering arginine metabolism and by increasing the activity of calcium independent nitric oxide synthase. ${ }^{29}$

Hence the probable mechanism of nephroprotection by Asgand (Withania somnifera) could be due to its antioxidant property and free radical-scavenging property and thus this plant could play a promising role in the treatment of acute renal failure induced by nephrotoxin like cisplatin. Literature on Unani Advia Mufrada (Single drugs) is so rich and having many drugs mentioned for nephroprotection by great scholars in their treatises. Many of them have proved by scientists in experiments. These may be evaluated on the scientific parameters for the treatment of chronic kidney disease. ${ }^{30-34}$

\section{ACKNOWLEDGEMENT}

The authors are thankful to the Honorable Vice Chancellor, Jamia Hamdard and Hamdard National Foundation, New Delhi for providing excellent facilities of academics and research to carry out this research work.

\section{REFERENCES}

1. Rozeneweig M, Van Hoff DD, Slavil M, Muggia FM, Cis-diamine dichloroplatinum, a new anticancer agent, Annals of Internal Medicine, 1977;86(6):803-809.

2. Livingston RB. Cisplatin in the treatment of solid tumors: effect of dose and schedule. J. National Cancer Institute, 1989; 81(10):724-725.

3. Kuhlmann MK, Burkhardt G, Kohler H, Insights into potential cellular mechanisms of cisplatin nephrotoxicity and their clinical application, Nephrol Dial. Tranplant, 1997; 12(12):2478-2480.

4. Garnick MB, Mayer RJ, Abelson HT. Acute renal failure associated with cancer treatment. In: Acute renal failure. Eds. B.M. Brenner \& J.M. Lazarus. Churchill Livingstone, New York; 1988. P. 621657.

5. Madias NE, Harrington JT, Platinum nephotoxicty, American Journal of Medicine, 1978; 65(1):307-314.

6. Goldstein RS, Mayor GH. The nephrotoxicity of cisplatin. Life Sciences, 1983; 32:685-690.

7. Zhang J, Lindup E, Cisplatin nephrotoxicity: decreases in mitochondrial protein sulphydryl concentration and calcium uptake by mitochondria from rat renal cortical slices, Biochem, Pharmacol, 1994; 47 (7):1127-1135.

8. Misitry P, Merazga Y, Spargo DJ, Riley PA, Mc Brien DCH, The effects of cisplatin on the concntration of protein thiols and glutathione in the rat kidney, Cancer Chemother. Pharmacol., 1991; 28(4):277-282.

9. Inselmann G, Blohmer A, Kottny W, Nellessen U, Heidemann HT, Modification of cisplatin-induced renal $\mathrm{p}$ aminohippurate uptake alteration and lipid peroxidation by thiols, Ginkgo biloba extract, desferroxamine and torbafyline, Nephron, 1995; 70(4):425-429.

10. Kandaswami C, Middleton Jr. E, Free Radical Scavenging and Antioxidant Activity of Plant Flavonoids, Free Radicals in Diagnostic Medicine, 1994; 366:351-376.
11. Sadzuka Y, Shoji T, Takino Y, Effect of cisplatin on the activities of enzymes which protect against lipid per oxidation, Biochem. Pharmacol., 1992; 43(8):1872-1875.

12. Offerman JJC, Meijer S, Sleijfer DT, Mulder NH, Donker AJM, Koops HS, Vander Hem GK, Acute effects of cisdiamminedichloroplatinum (CDDP) on renal function, Cancer Chemother, Pharmacol., 1984; 12(1):36-38.

13. Li Q, Bowmer CJ, Yates MS, Effect of arginine on cisplatininduced acute, renal failure in the rat, Biochem. Pharmacol. 1994; 47(12):2298-2301.

14. Nakano S. Gemba M, Potentiation of cisplatin-iduced lipid peroxidation in kidney cortical slices by glutathione depletion, Jpn J Pharmacol., 1989; 50(2):87-92.

15. Zhong LF, Zhang JG, Zhang M, Xia YX, Protection against cisplatin induced lipid peroxidation and kidney damage by procaine in rats, Arch Toxicol., 1990; 64(7):599-600.

16. Baldew GS, Van den Hamer CJA, Los G, Vermuelen NPE, de Goej JJM, McVie JG, Selnium induced protection against cisdiaminodichloroplatinum nephrotoxicty in mice and rats, Cancer Research., 1989; 49(11):3020-3023.

17. Anonymous, "Unani system of Medicine, The Science of health and healing", Department of AYUSH, Ministry of Health and family welfare publication, New Delhi, 2013.

18. Ghani N. Khazainul Advia. Vol-II, Barqi press Lahore. 1926. P. 7981.

19. Khan MA. Muheet-e-Azam. (urdu translation), vol-I, Central council for Research in Unani Medicine Publication, New Delhi, 2012. P. 319-320.

20. Azhar MU, Alam M, Aslam M, Javed K, Jarfi MA, Role of Asgand (Withania somnifera Dunal) in cadmium chloride induced nephrotoxicity in rats, Hamdard Medicus, 2005; 48(3):48-51.

21. Alam MMA, Javed K, Jafri MA. Effect of revand (Rheum emodi) on renal functions in rats. Journal of Ethnopharmacology, 2005; 96(1-2):121-125.

22. Azhar MU, Khan SA, Aslam M, Javed K, Jarfi MA Nephroprotective activity of kulthi (Dolichos biflorous) on gentamicin induced toxicity in rats, Journal Science and Pharmacy, 2004; 5(2):50-53.

23. Azhar MU, Tajuddin, Jafri MA, Nephroprotective effect of kulthi [Macrotyloma uniflorum (lam) verdc.] on acute renal failure in rats, Hippocratic Journal of Unani Medicine, 2008; 3(4):97-102.

24. Alam M, Javed K, Jafri MA, Effect of oleo-gum-resin of Boswellia serrata (Kundur) on renal functions in Albino rats, Indian Journal of Traditional Knowledge, 2011; 10(4):736-740.

25. Akhtar F, Azhar MU, Aslam M, Javed K, Nephroprotective effect of Khar-e-Khasak Khurd (Tribulus terristris linn) on gentamicininduced experimental nephrotoxicity in rats, Asian Journal of Research in Nephrology, 2020; 3(3):6-13.

26. Javaid R, Aslam M, Javed R, Nizami Q, Javaid K, Azhar MU, Extract of ferula foetida Regal reverses gentamicin induced nephrotoxicity in rats, Experimental and Clinical Sciences Journal, 2012; 11-1-7.

27. Rao M, Rao MNA, Protective Effect of Cystone a polyherbal Ayurvedic preparation on cisplatin induced renal toxicity in rats, Journal of Ethnopharmacology, 1998; 62(1):1-6.

28. Godkar PB. Text Book of Medical Laboratory Technology Bhalani Publishing House, Bombay, 1994. P. 174-185.

29. Devipriya S, Shyamaladevim CS, Protective effect of quercetin in cisplatin induced cell injury in the rat kidney, Indian J. Pharmacol., 1999; 31(6):422-426.

30. Azhar MU, Anjum N, Quddusi N, Akhtar J, Akram U, Yadav PK Pharmacologically active nephroprotective plants- a review, Hamdrad Medicus, 2013; 56:56-76.

31. Azhar MU, Javed K, Jarfi MA, Plant with nephroprotective activity, Hamdard Medicus, 2005; 48(4):33-43.

32. Azhar MU, Akhtar F, Aslam M, Anwer M, Tajuddin, Jafri MA Nephroprotective activity of some herbal preparations, Hamdard Medicus, 2005; 49(1):110-115.

33. Azhar MU, Effect of herbal unani formulation on nephrotic syndrome: a case study, Indian Journal of Traditional Knowledge, 2018; 17(4):807-810.

34. Azhar MU, Mustehasan, Alam M, Ahmad SG, Anjum N, Quddusi N, Nephroprotective unani drug Khar-e-Khasak Khurd (Tribulus terrestris linn.) - a review, International Journal of Scientific Research in Biological Sciences, 2020; 7(1):24-36. 